\title{
Burden of industrial waste and potential for recycling: technological, economic and environmental aspects
}

\author{
Ivan MIHAJLOVIĆ \\ University of Belgrade, Bor, Serbia \\ imihajlovic@tfbor.bg.ac.rs
}

\begin{abstract}
Many benefits resulting from the development of the heavy industry are, unfortunately, accompanied by many issues resulting from the process of generating the industrial waste. This manuscript is presenting the environmental consequences, resulting from long period of time of heavy industry production and exploring the possibilities to recycle some of the industrial waste generated during the period of more than one century of ore excavation and copper extraction in the region of Eastern Serbia, in the vicinity of city of Bor. First part of the manuscript is presenting the scope of environmental issues, resulting from the heavy industry in this region and the amounts and the structure of the industrial waste, generated in this area, as well as the influence of generated waste to the environment of the region. Second part of the manuscript is dealing with the potential to recycle and reuse some of this waste, analyzing technological, economic and environmental aspects at the same time. In the final segment of the paper, some practical examples will be addressed based on the research work conducted at both experimental and industrial level. Results presented in the manuscript are mostly collected during long term research of the project team from Technical faculty in Bor, University of Belgrade, in the field of environmental management. This way, this manuscript is based on review of the research papers authored or co-authored by the author of this work, dealing with water, soil and air pollution, published in leading international journals. Also, the manuscript is presenting the literature review of other international issues dealing with the environmental management issues in the vicinity of large industrial complexes. Parts of the research results, presented in this manuscript are financially supported by the Ministry of Education, Science and Technological development of Republic of Serbia, under the project TR34023.
\end{abstract}

Keywords: industrial waste, recycling, environmental management.

\section{Introduction}

Industrial development, which started by the end of $18^{\text {th }}$ and lasted up to middle of $19^{\text {th }}$ century, have broth many positive elements to the development of modern civilization. Being the the process of change from an agrarian, handicraft economy to one dominated by industry and machine manufacture, as the result the production capacities increased, enabling the increase of number of workplaces in production facilities, as well as larger consumption of consumer gods. Also, it resulted in diversification of quality of products and services, this way enabling availability of certain goods people of the middle and lower class, which were exclusively available only to the rich population in the past.

However, besides many positive consequences, industrialization introduced one new paradigm in our living environment, which was not existed before the industrial revolution, that is pollution and industrial waste accumulation. This become especially evident in the period of so called second industrial revolution, which take place in late $19^{\text {th }}$ and $20^{\text {th }}$ centuries.

In terms of basic materials, during the second industrial revolution, modern industry began to exploit many natural and synthetic resources not hitherto utilized: lighter metals, 
new alloys, and synthetic products such as plastics, as well as new energy sources. Combined with these were developments in machines, tools, and computers that gave rise to the automatic production (Encyclopedia Britannica, 2016). The new material development and use in peoples everyday life, lead to increase of new materials, which appeared to be highly toxic, when discharged in the environment, and as most important issue, impossible to be decomposed and absorbed naturally, for the long period of time.

PICBE | 56

It wouldn't be .... To say, that during the $20^{\text {th }}$ century, the industrial production was overdeveloped, e.g. the development and increase of the production facilities was in such ratio that it was not adequately followed with the environmental policies and environmental awareness about negative influence and long term consequences of waste materials emitted to the water, soil and land. This was especially a case in the lower developed economies and countries in transition, where development of the environmental regulations and legislatives are still behind the level achieved in well developed western societies.

This article is dealing with the environmental influences and consequences of one century of copper production in one of the largest copper mining and extraction facilities, located in city of Bor, Serbia, South East Europe. The structure of industrial waste, generated during this period of operation will be explained in the first part of the manuscript, while the potential for some remediation and reuse of some parts of this waste, will be described in the second part of the manuscript.

\section{Environmental consequences of one century of copper production}

The Municipality of Bor encompasses an area of $856 \mathrm{~km} 2$ in the central part of Eastern Serbia; around $100 \mathrm{~km}$ from the Romanian and $30 \mathrm{~km}$ from the Bulgarian border (Fig. 1). The population density of the Municipality is 67.2 inhabitants per $\mathrm{km}^{2}$. The altitude of the town Bor, $378 \mathrm{~m}$, is low compared with the surrounding high mountains (Stol $1156 \mathrm{~m}$, Veliki Krs $1146 \mathrm{~m}$ and Crni Vrh $1043 \mathrm{~m}$ ). Wood soil covers $45 \%$ of the area of the Municipality of Bor; the remainder is $49 \%$ agricultural soil and $6 \%$ infertile soil. The climate is moderate continental. The average mean annual rainfall is around $469.2 \mathrm{~mm} \mathrm{~m}^{-2}$, snow coverage lasts about 60 days and the annual average temperature is $11.7^{\circ} \mathrm{C}$. The annual average mean relative air humidity is $73 \%$, while the average atmospheric pressure is 971 mbar. The prevailing wind is WNW with an average velocity of $0.5 \mathrm{~m} \mathrm{~s}^{-1}$; the wind still period is over $50 \%$ (Nikolić et al., 2010a). 


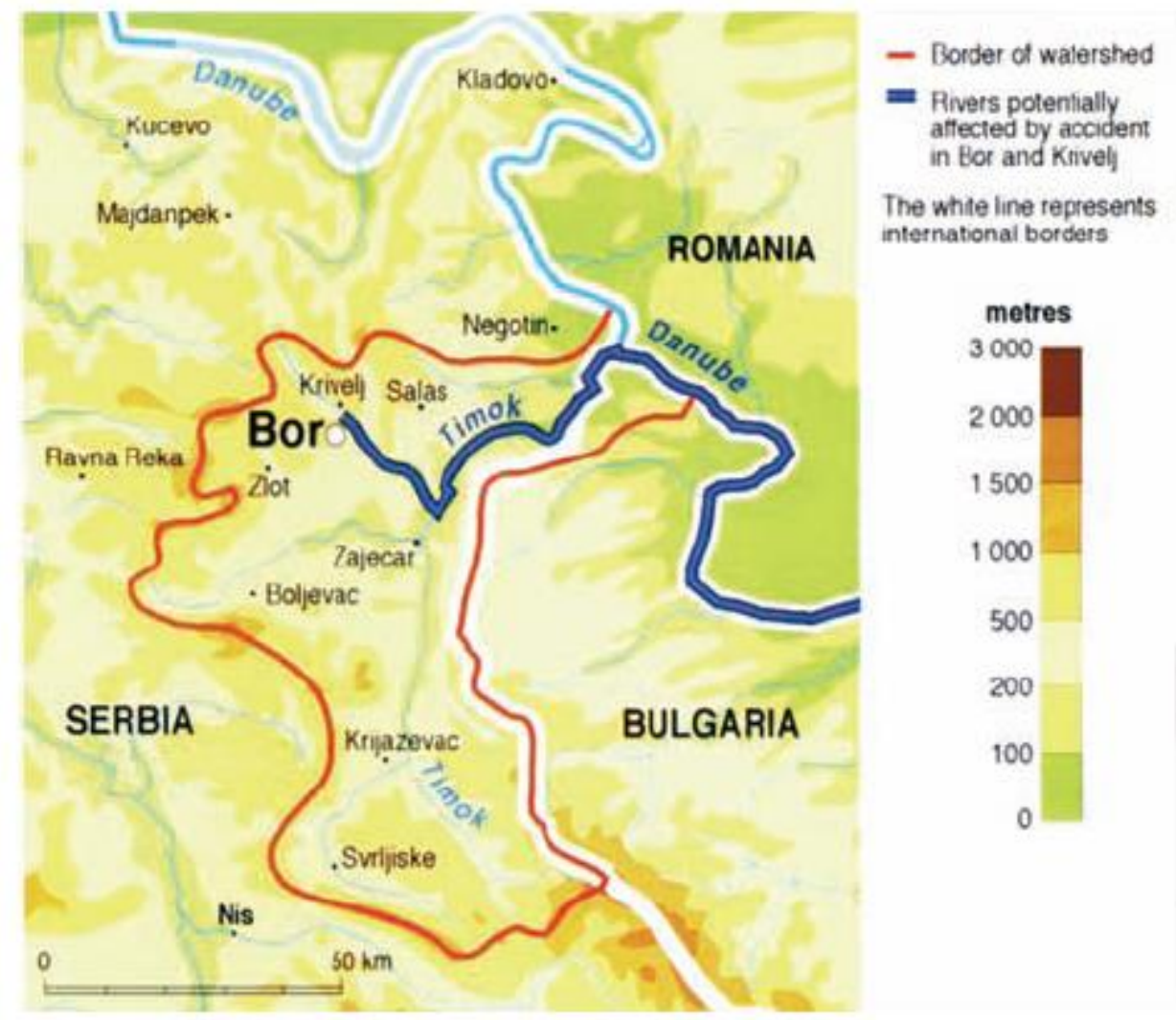

Figure 1. Map of the studied area in the surroundings of the Copper Smelter Bor, Serbia

Source: Nikolić et al., 2010a.

The RTB Bor Copper Smelting Plant, a part of the RTB Mining and Smelting Complex, is located in the town Bor. Production in Bor commenced in 1903 by underground mining. The mine is located on the north-eastern rim of the town; the open pit, the metallurgicalsmelting complex and the flotation tailings pond make a boundary between the urban and the industrial zone. Due to the fact that the town was built in the near vicinity of the mine, as well as near the location of the copper smelting plant and two further mines close by, the town itself represents a serious environmental hot spot of Serbia and Europe.25 The Bor River (industrial river), representing one of the most polluted rivers in the world, flows into the Timok River, a tributary of the Danube River (Fig. 1) (Nikolić et al., 2010a).

Until the mid-2015, the technology process employed in the RTB Bor Copper Smelting Plant, was largely outdated and based on the old reverberatory furnace. This technology is based on classical pyrometallurgy, with smelting in reverberatory furnaces and a relatively low degree of sulfur dioxide $\left(\mathrm{SO}_{2}\right)$ gas utilization $(<50 \%)$ for the production of sulfuric acid. This lead to emission of large quantities of $\mathrm{SO}_{2}$, in the concentration much above prescribed maximal limited values (MLV), accompanied by emission of the toxic airborne particle matter $\left(\mathrm{PM}_{10}\right)$, , as well as aero-sediments even larger than the $\mathrm{PM}_{10}$ particles, containing increased quantity of heavy metals (Nikolić et al., $2010 \mathrm{~b}$ ). This lead to degradation of a huge soil area, a huge volume of the soil waste generated over the years and pollution of underground and surface waters. Unfortunately, such consequences are the main attribute for most activate or closed mines and copper smelting plants in the world. 
Besides large quantity of waste, generated through the output of the industrial process, additional large environmental risk exists in this king of pyrometalurgical production. The most important types of copper ores, for pyrometallurgical production, are sulfides. The process of copper extraction from sulfide minerals in the smelter plant requires special ore preparation and transformation in the form of copper concentrate. The $\mathrm{Cu}$ content in the ore is in the range $0.6-1 \%$, while, the $\mathrm{Cu}$ content in the concentrate ready for smelting operation should be $20 \%$ or above. Such ore preparation is based on the flotation process. Considering that, process of flotation should remove waste and gangue minerals, from the minerals contacting coper, this leads to generation of new large quantities of flotation wastes, disposed at the tailing pond in the near vicinity of the copper smelter, located there to reduce the transportation costs. Unfortunately, based on the location of the copper smelter, these tailing ponds are also in the near vicinity of the city (Figure 2). Copper flotation waste (which refers to the remaining impurities), generally contains significant amounts of remaining $\mathrm{Cu}$ together with trace elements of other toxic materials such as $\mathrm{Fe}, \mathrm{Sn}, \mathrm{Sb}, \mathrm{As}$, and $\mathrm{Pb}$.

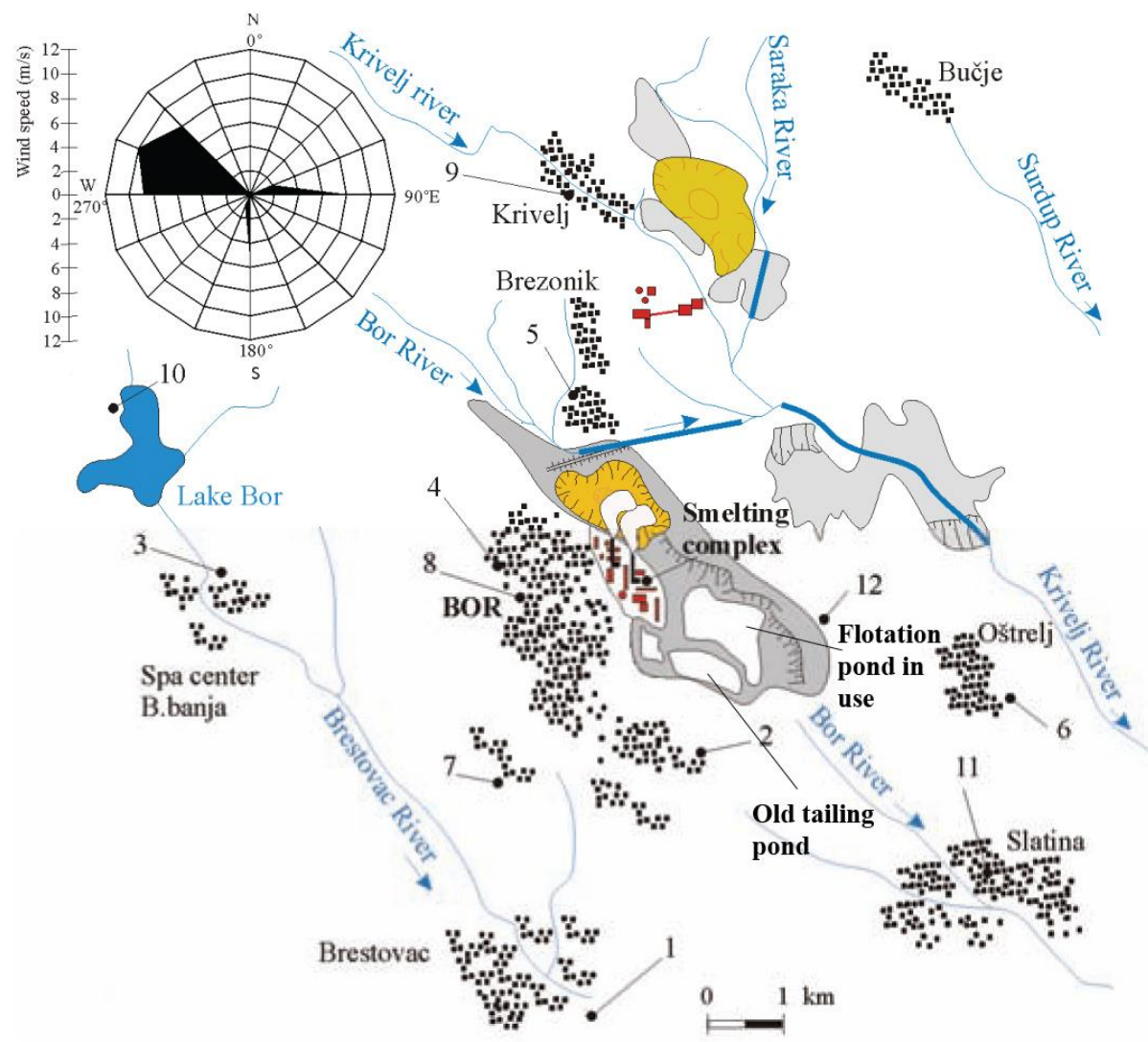

Figure 2. Location of the flotation tailings ponds near the city of Bor

Source: Mihajlović et al., 2012

Copper flotation waste generated from copper industry is classified as hazardous waste according to European Union directive concerning integrated pollution prevention (EU Directive, 1996) as well as the Mining Waste Directive (EU Directive, 2006). According to (Gorai and Jana, 2003), for every ton of metal production ca. 2.2 ton of copper flotation 
waste is generated. Furthermore, approximately 24.6 million tons of copper flotation wastes are generated each year from world copper production (Habashi, 2009). Because of this excess, copper flotation wastes are generally disposed of without any prior solid waste treatment in areas around the industry. Due to spontaneous leaching into water courses, disposed hazardous waste containing $\mathrm{Cu}$ and other toxic metals is highly dangerous pollutant affecting human health and the surrounding physical environment (Antonijević et al., 2008; Kersch et al., 2004; Mihajlović et al., 2012). Some additional details about possibilities to re-use this material and to perform the soil remediation are presented in the next part of this manuscript.

During the year 2015, the new contemporary process for copper smelting, based on the autogenous flash smelting technology have replaced the old reverberatory furnace. This largely limited the amount of impurities emitted with off gases and industrial water, however, the consequences of one century of ore mining and processing, based on old technology are still remaining in the region.

\section{Research results}

Bearing in mind that waste was accumulated in earlier years without any processing, it is estimated that about $10^{8}$ metric tons of waste have been stored at the Bor copper mine deposit (Đurić et al., 2010). Large areas covered with tailings are a source of mineral dust. The dust from this location, in the form of $\mathrm{PM}_{2.5}$ and $\mathrm{PM}_{10}$, is dispersed towards the urban area and the areas of fertile land depending on the wind rose and the time of the year. In the past, this was also accompanied by the large $\mathrm{SO}_{2}$ and $\mathrm{PM}$ emission resulting directly from the smelting process off gases.

In the wider area of the town of Bor, there are around 200000 inhabitants whose health is imperilled by the soil and water contamination. This location is a very high -risk area per European standards (Dimitrijević et al., 2009; LEAP, 2003). Research conducted by various authors (Nikolić et al., 2011; Dimitrijević et al., 2009; Mihajlović et al., 2010) unmistakably shows that this area was the most polluted area in south-eastern Europe which forces the management of the company to take action aimed at global resolution of the problem.

The results on measurement and modeling of $\mathrm{SO}_{2}$ distribution in air, at different location in city of Bor, resulting from the smelter plant operation, are published by the project group from TF Bor, in Savić et al., 2013; Nikolić et al., 2010b and Đorđević et al., 2013. The average monthly $\mathrm{SO}_{2}$ concentrations at particular measuring locations, which were the part of the monitoring system of the town of Bor in 2011, are shown in Figure 3. 


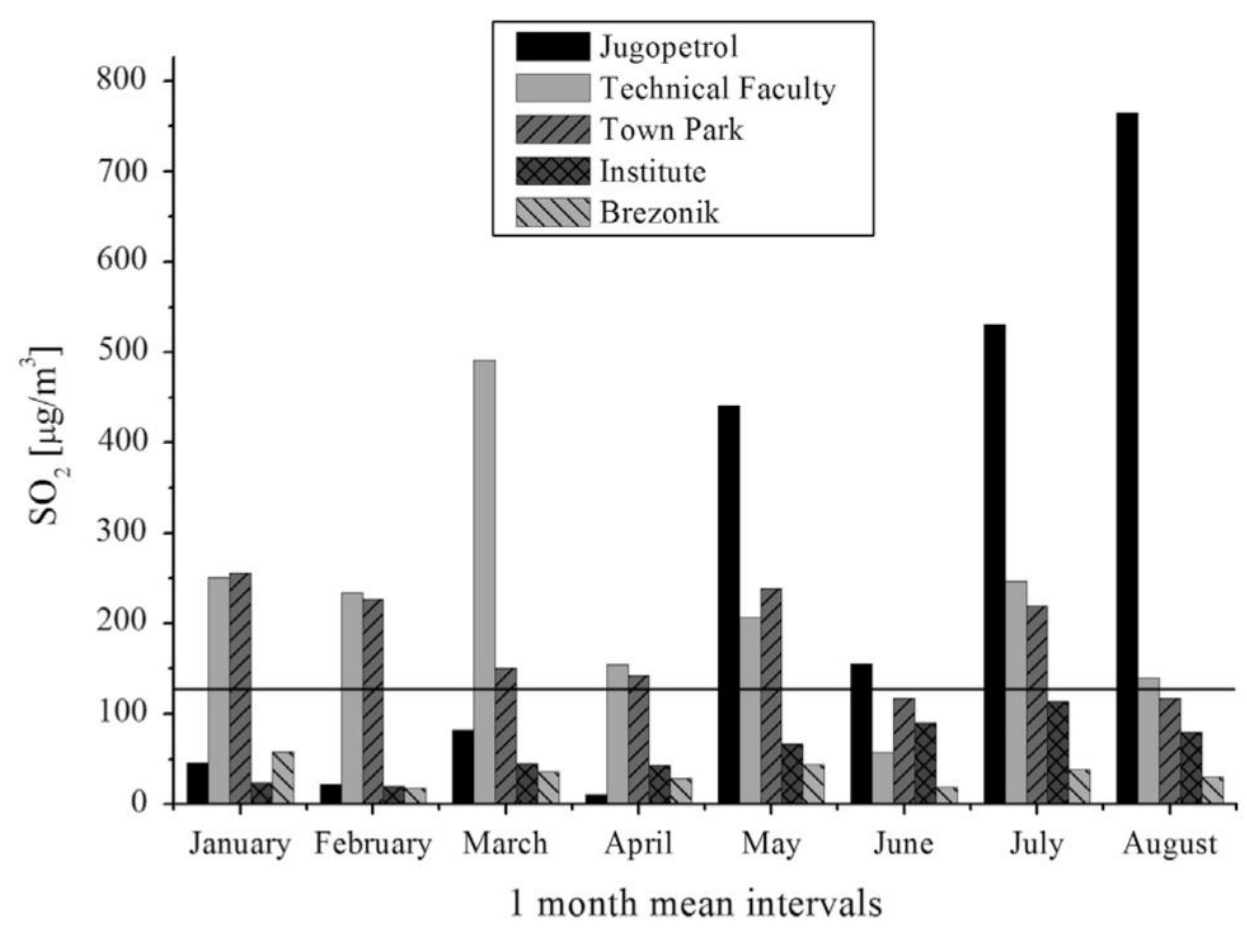

PICBE $\mid 60$

Figure 3. Average monthly SO2 concentrations in the air in 2011.

Source: Đorđević et al., 2013

While, the highest contents of some heavy metals were found in the samples taken from the different locations (Figure 2) near to the town center (Table 1). The wind "rose" (Fig. 2) for the period 2005-2008 indicates that the WNW (west-northwest) wind direction is prevalent during the year (approximately $30 \%$ ) which led to the highest degree of air pollution in this part of the town (measuring points 4 and 8 - City Hospital and the city location "Šumska sekcija - Forest Section", respectively). The following objects are located in this part of the town: the old town center, a hotel, the town market, the town hall building, the faculty campus, an elementary school and the city hospital. With increasing distance from the plant stacks, the soil pollution decreased and it is minimal was at a distance of $20 \mathrm{~km}$ (measuring point 10- Lake Bor); however the influence of pollution was still apparent.

Fortunately during the year 2015, the new contemporary process for copper smelting, based on the autogenous flash smelting technology have replaced the old reverberatory furnace. This largely limited the amount of impurities emitted with off gases and industrial water, however, the consequences of one century of ore mining and processing, based on old technology are still remaining in the region.

On the other hand, complete remediation of the flotation tailings ponds requires huge investments. Many active mines in the world are affected by weathering of their tailing ponds (Ciccu et al., 2003; Forsberg et al., 2006; Bartocchi et al., 2006). This situation is worse after closure of the mine. Most often, flotation tailings ponds remain only partly stabilized, presenting a large environmental hazard (Benvenuti et al., 1997; Bryan et al., 2009). 
Table 1. Evaluation table. Heavy metals concentrations ( $\left.\mathrm{mg} \mathrm{kg}^{-1}\right)$ in the soil at 12 locations in the urban area of the town Bor and its surroundings

\begin{tabular}{|c|c|c|c|c|c|c|c|c|}
\hline \multirow[t]{2}{*}{ Measuring location } & \multicolumn{8}{|c|}{ Metallic compound concentration in sediments } \\
\hline & $\mathrm{pH}$ & $\mathrm{Cu}$ & $\mathrm{Pb}$ & $\mathrm{Cd}$ & $\mathrm{Ni}$ & $\mathrm{Mn}$ & As & $\mathrm{Hg}$ \\
\hline Location 1 & 7.7 & 530 & 70 & 2 & 45 & 1100 & 17 & $<0.1$ \\
\hline Location 2 & 7.6 & 1050 & 100 & 4 & 33 & 880 & 68 & 0.1 \\
\hline Location 3 & 7.5 & 550 & 60 & 2 & 33 & 1300 & 52 & 0.1 \\
\hline Location 4 & 7.4 & 2540 & 180 & 6 & 49 & 1200 & 260 & 0.3 \\
\hline Location 5 & 7.9 & 770 & 80 & 2 & 12 & 1200 & 33 & 0.1 \\
\hline Location 6 & 7.8 & 390 & 40 & 2 & 41 & 1200 & 15 & $<0.1$ \\
\hline Location 7 & 6 & 1000 & 40 & $<2$ & 37 & 1200 & 23 & $<0.1$ \\
\hline Location 8 & 7.2 & 2140 & 230 & 5 & 53 & 1100 & 140 & 0.3 \\
\hline Location 9 & 6 & 580 & 60 & 2 & 16 & 1200 & 25 & 0.1 \\
\hline Location 10 & 7.5 & 220 & 50 & 3 & 37 & 460 & 19 & $<0.1$ \\
\hline Location 11 & 7.7 & 930 & 80 & 3 & 49 & 900 & 41 & 0.1 \\
\hline Location 12 & 7.7 & 260 & 50 & $<2$ & 37 & 1100 & 16 & 0.1 \\
\hline Max. value & & 2540 & 230 & 6 & 53 & 1300 & 260 & 0.3 \\
\hline Average value & & 913.33 & 86.67 & 2.92 & 36.83 & 1070 & 59.08 & 0.133 \\
\hline $\begin{array}{l}\text { Limit values according to the National } \\
\text { legislation of the Republic of Serbia }\end{array}$ & & $<100$ & $<100$ & $<3$ & $<50$ & $-{ }^{a}$ & $<25$ & $<2$ \\
\hline
\end{tabular}

Source: Nikolić et al., 2011.

Chemical composition of flotation tailing sample is given in Table 2. It is obvious, that this material still contains large quantities of copper. Having in mind high copper price at the Worlds market, copper extraction from this material, can also generate additional income which could be partially used for remediation and safe disposal of the waste material remaining after copper extraction.

Table 2. Chemical characterization of the flotation tailings

\begin{tabular}{llll}
\hline Component & $\begin{array}{l}\text { Concentration } \\
{[\text { wt. \%] }}\end{array}$ & Component & $\begin{array}{l}\text { Concentration } \\
\text { [wt. \%] }\end{array}$ \\
\hline $\mathrm{Cu}_{\text {cum }}$ & 0.24 & $\mathrm{SiO}_{2}$ & 56.72 \\
$\mathrm{Cu}_{\text {ox }}$ & 0.05 & $\mathrm{Al}_{2} \mathrm{O}_{3}$ & 12.64 \\
$\mathrm{Cu}_{\text {sulf }}$ & $\mathrm{Fe}$ & 8.65 \\
$\mathrm{~S}$ & 0.235 & $\mathrm{Zn}$ & 0.005 \\
$\mathrm{As}$ & 10.56 & $\mathrm{Mn}$ & 0.011 \\
$\mathrm{~Pb}$ & 0.026 & $\mathrm{CaO}$ & 0.95 \\
$\mathrm{Sn}$ & 0.003 & $\mathrm{MgO}$ & 0.052 \\
$\mathrm{Sb}$ & 0.0071 & $\mathrm{remaining}$ & $<10$ \\
$\mathrm{Ba}$ & 0.003 & $\mathrm{Au}(\mathrm{g} / \mathrm{t})$ & 0.1 \\
$\mathrm{Sr}$ & 0.0048 & $\mathrm{Ag}(\mathrm{g} / \mathrm{t})$ & 1.1 \\
\hline
\end{tabular}

Several methods have been proposed to reduce or eliminate the problem arising from the flotation tailings ponds (Djuric et al., 2010; Mihajllović et al., 2010). One of the 
methods was based on acidic leaching of kaolinite from the flotation waste (Djuric et al., 2010) which resulted with obtaining the kaolinitic concentrate containing 32\% Al203. Other methods included vitrification of copper flotation waste, with possibility of subsequent leaching of vitrified product. One of attempts was the immobilization of heavy metals in copper flotation waste using fly ash followed with leaching in various leachants (Mihajllović et al., 2010).

The results of the own research of the project team from Technical, based on the idea to investigate the possibility of copper utilization from the flotation waste collected from copper industry in Bor during the years of extraction is presented in (Mihajlović et al., 2012). The approach undertaken in this study was based on the method of factorial experimental design applied on obtaining the mathematical model which will include all important experimental factors at the same time. The most important experimental factors and the possible range of each experimental variable values, as the starting point of the modelling procedure were based on literature review and previous research. As the result of this approach, it was possible to design the experimental setup with the optimum process conditions that might yield the highest copper utilization.

Using the methodology described in details in the (Mihajlović et al., 2012), it was determined that more than $80 \%$ of copper can be extracted from the flotation waste using the hydrometallurgical process of sulfurization and leaching. Based on the fact that in $10^{8}$ metric tons, with the average $\mathrm{Cu}$ content of $0.24 \%$, this is the amount of $0.8 \times 10^{8} \times 0.24 / 100=$ $1.92 \times 10^{5}$ metric tons of copper. With the copper price of 5888 USD/ton (LME on January 2017), this means that more than 1.13 billion of USD are stored in this tailing pound.

\section{Conclusion}

The results presented in this manuscript are based on literature review and practical examples, explaining the consequences of more than one century of heavy industry development in the region of the city of Bor (East Serbia). The aim of this manuscript is to present the negative environmental consequences, which are accompanying all the positive influences of industrialization.

Also, possibilities for recycling and re-use of some parts of the industrial waste generated are presented in the manuscript. Based on the estimation of quantities of the copper, still remaining in this waste material, the potential economic effect of recycling this material is also presented. On the other hand, the economic effect is just presented as the rough estimation, accordingly, leading to conclusion that the extension of this research should be based on detailed economic analysis (including ROI, Cost - Benefit analysis, etc), in the future work.

\section{References}

Antonijević, M.M., Dimitrijević, M.D., Stevanović, Z.O., Serbula, S.M., Bogdanovic, G.D. (2008). Investigation of the possibility of copper recovery from the flotation tailings by acid leaching. Journal of Hazardous Materials, 158 (1), 23-34.

Benvenuti, M., Mascaro, I., Corsini, F., Lattanzi, P., Parrini, P., Tanelli, G. (1997). Mine waste dumps and heavy metal pollution in abandoned mining district of Boccheggiano (Southern Tuscany, Italy). Environmental Geology, 30 (3), 238 - 243. 
Bertocchi, A.F., Ghiani, M., Peretti, R., Zucca, A. (2006). Red mud and fly ash for remediation of mine sites contaminated with $\mathrm{As}, \mathrm{Cd}, \mathrm{Cu}, \mathrm{Pb}$ and $\mathrm{Zn}$. Journal of Hazardous Materials, 134 (1-3), 112 - 119.

Bryan, C.G., Hallberg, K.B., Johnson, D.B.(2006). Mobilisation of metals in mineral tailings at the abandoned São Domingos copper mine (Portugal) by indigenous acidophilic bacteria. Hydrometallurgy. 83 (1-4), 184-194.

Ciccu, R., Ghiani, M., Serci, A., Fadda, S., Peretti, R., Zucca, A. (2003). Heavy metal immobilization in the mining-contaminated soils using various industrial wastes. Minerals Engineering, 16 (3), 187 - 192.

Dimitrijević, M., Kostov, A., Tasić, V., Milosević, N. (2009). Influence of pyrometallurgical copper production on the environment. Journal of Hazardous Materials, 164 (2-3), $892-899$.

Djuric, I., Mihajlovic, I., Bogdanovic, D., Zivkovic, Z. (2010). Modelling the process of kaolinite leaching from a copper mine flotation waste. Clay Minerals, 45 (1), 107-114.

EU Directive, Council Directive 96/61/EC of 24 September 1996 concerning integrated pollution prevention and control, Official Journal L 257, 1996, 0026.

EU Directive, Council Directive 2006/21/EC of 15 March 2006 on the management of waste from extractive industries and amending Directive 2004/35/ECl, Official Journal L 102, 2006, 15.

Forsberg, L.S., Ledin, S. (2006). Effects of sewage sludge on $p H$ and plant availability of metals in oxidising sulphide mine tailings. Science of The Total Environment, 358 (1-3), 21 35.

Gorai, B., Jana, R.K. (2012). Characteristics and utilisation of copper slag - a review, resources. Conservation and Recycling, 39(4), 299-313.

Habashi F. (2009). Recent trends in Extractive metallurgy. Journal of Mining and Metallurgy, Section B: Metallurgy, 45 (1), 1-13.

Kersch, C., Peretó Ortiz, S., Woerlee, G.F., Witkamp, G.J. (2004). Leachability of metals from fly ash: leaching tests before and after extraction with supercritical $\mathrm{CO}_{2}$ and extractants. Hydrometallurgy, 72 (1-2), 119 / 127.

LEAP-Local Environmental Action Plan Bor, Municipality of Bor, Serbia, 2003.

Mihajlović, I., Nikolić, Đ., Štrbac, N., Živković, Ž. (2010). Statistical modelling in ecological management using the artificial neural networks (ANNS). Serbian Journal of Management, 5 (1), 39-50.

Mihajlović, I., Štrbac, N., Đorđević, P., Mitovski, A., Nikolić, Đ., Živković, Ž. (2012). Optimum conditions for copper extraction from the flotation waste using factorial experimental design. Environment Protection Engineering, 38(4), 171-184.

Nikolić, Đ., Milošević, N., Živković, Ž., Mihajlović, I., Kovačević, R., Petrović, N. (2010a). Multicriteria analysis of soil pollution by heavy metals in the vicinity of the Copper Smelting Plant in Bor (Serbia). Journal of the Serbian Chemical Society, 76 (4), 625641.

Nikolić, Đ., Milošević, N., Mihajlović, I., Živković, Ž., Tasić, V., Kovačević, R., Petrović, N. (2010b). Multi-criteria analysis of air pollution with SO2 and PM10 in urban area around the copper smelter in Bor, Serbia. Water Air and Soil Pollution, 206, 369-383.

The Editors of Encyclopedia Britannica (2016). Industrial Revolution, available at: https://www.britannica.com/event/Industrial-Revolution. 